ISSN 0258-7122 (Print), 2408-8293 (Online)

Bangladesh J. Agril. Res. 44(2): 327-337, June 2019

\title{
WOMEN PARTICIPATION IN ROOFTOP GARDENING IN SOME AREAS OF KHULNA CITY
}

\author{
S. NASRIN ${ }^{1}$, M. M. ISLAM ${ }^{2}$, M. A. MANNAN ${ }^{3}$ \\ AND M. B. AHMED ${ }^{4}$
}

\begin{abstract}
Khulna is the largest city corporation in the southwestern region of Bangladesh where rooftop gardening is gradually gaining popularity among the city dwellers. The main purpose of the study was to assess the extent of participation of women in rooftop gardening in Khulna city and to explore the relationship between each of the selected characteristics of women and their extent of participation in rooftop gardening. Primary data were collected from randomly selected 92 women during the period of 20 March to 10 April, 2018 at Rayermahal, Khalishpur, Daulatpur and Maheshwarpasha areas under Khulna city. Most (94.57\%) of the women had medium participation, 3.26\% had high participation, and $2.17 \%$ had low participation. Considering four aspects, the women had higher participation in preparatory stage (Participation Extent $(\mathrm{PE})=$ $59.87 \%)$ whereas it was least in harvesting stage $(\mathrm{PE}=34.06 \%)$. Considering the twenty issues under four aspects of rooftop gardening, the highest participation by the women was in watering the garden $(\mathrm{PE}=88.04 \%)$ and no participation was in marketing $(\mathrm{PE}=0 \%)$. Among ten selected characteristics level of education $(P<0.05)$, agricultural training, attitude towards rooftop gardening, and knowledge about rooftop gardening $(P<0.01)$ had significant positive relationships with participation of women in rooftop gardening. By designing women friendly extension approach for rooftop gardening barrier free participation of the city dwelling women should be fostered.
\end{abstract}

Keywords: Participation, Women, Rooftop gardening

\section{Introduction}

Bangladesh is a densely populated country. The buildings in city areas are increasing. For this reason people are cutting trees to fulfill the need of city expansion. So, to compensate the tree reductions in the cities new plantation is needed. Trees are needed for green environment, human nutrition, added income and aesthetic beauty. But, there is no land left for plantation. Rooftop gardening is an alternative way to meet the demand for plantation. Now people are becoming more interested in rooftop gardening, especially in city areas. Many of the peoples' hobbies are gardening. It was the German architect Von Rabitz, (Abram, 2006) who first spread the modern concept of rooftop gardening. People can meet their nutritional demand through sowing vegetables, fruits, and corns on

\footnotetext{
${ }^{1}$ Ex-student of MS in Agricultural Extension and Rural Development; ${ }^{2}$ Associate Professor, ${ }^{3 \& 4}$ Professor, Agrotechnology Discipline, Khulna University, Khulna, Bangladesh.
} 
roof garden. Through roof gardening people can create a healthy environment in the city areas. In urban areas, vegetation is a significant contributor to the reduction of air pollutions (Nowak, 2004 and Akbari et al., 2001).

Women can ensure the production of pure and nutritious vegetables and fruits through their participation by small scale rooftop agriculture as they mostly reside in the house. The roof can be a source of income. It can refresh the mind also. The gardening on the roof top transformed the physical and visual aesthetic of the barren concrete structure into a living and breathing green space (Cantor, 2008; Grant, 2006). Rooftop garden provides good aesthetic look. It also creates biodiversity in nature, through the presence of different kinds of birds and the rarest species of insects (Chrisman, 2005). It can also become a nest for birds and native avian communities (Baumann, 2006). Roof garden has also economic value. From roof gardening people can earn money by selling the vegetables, fruits, and corns in the market. But in city areas, people use roof garden mainly for aesthetic purpose rather than economic purpose. The vegetation and waterproof membrane of green roofs alleviate the temperature of the roof and extend its life by more than 20 years (USEPA, 2000). Rooftop gardens are most suitable solution for the reduction of the external surface temperature in any climate (Costanzo et al., 2016). In Singapore, green roofs reduce cooling load by $10 \%$ of the usual building with a conventional roof (Wong et al., 2003). Green roof not only reduces heat but also reduces storm water runoff (Weiler and Scholz, 2009). Water runoff is held by the vegetation and soil before it directly hits the ground. Therefore, it reduces storm water runoff. Furthermore, rooftop farm lowers the carbon footprint caused by trucks used to transport food into the city (Rowe et al., 2006).

Sheel et al. (2019) also conducted their research on rooftop gardening in Khulna city, and they found that $56.67 \%$ of the respondents were the owners of medium size actual roof area (1001-2000 $\left.\mathrm{ft}^{2}\right)$; and $65 \%$ respondents owned small roof area $\left(\leq 1000 \mathrm{ft}^{2}\right)$ suitable for gardening. They reported that actual roof area under gardening was small area $\left(\leq 500 \mathrm{ft}^{2}\right)$ in case of $56.67 \%$ respondents. Quasem (2011) reported that conversion of agricultural land to non-agricultural land is at the rate of $0.26 \%$ (2001-'08) in Khulna city. Due to decline in agricultural land, overall national production is declined and problem of food insecurity is becoming more intense. In that case, rooftop agriculture is one way in which urban areas could attempt to be more balanced and sustainable in their resource consumption where the city dwelling women can functionally participate.

Only a little research has been conducted in home and aboard to determine the participation of the women in rooftop garden. The major focus of the study was to assess the participation of women in rooftop gardening. For this reason, the study was undertaken with the specific objectives:

1) To determine the extent of women participation in rooftop gardening;

2) To assess some selected characteristics of the women who participate in rooftop gardening; and 
3) To explore the relationship between the selected characteristics of the women and their extent of participation in rooftop gardening.

\section{Methodology}

The study was conducted in Khulna which is a rapidly growing city in terms of multistoried building construction. A list of 200 female rooftop garden owners was prepared with the help of the concerned Sub-Assistant Agriculture Officers of the area of Rayermahal, Khalishpur, Daulatpur and Maheshwarpasha under the jurisdiction of Metropolitan Agriculture Office of Khulna city. Primary data were collected from randomly selected 92 (46\% of the total number) women during the period from 20 March to 10 April, 2018. Data were collected through face-toface interview using a pre-tested interview schedule containing both close and open type of questions. Participation of women in rooftop gardening was considered focus issue in this study and ten characteristics such as age, level of education, family size, annual family income, cosmopoliteness, extension contact, agricultural training, organizational participation, attitude towards rooftop gardening, and knowledge about rooftop gardening of the women were selected for the study.

Participation score in rooftop gardening was determined by using the following formula:

$$
\mathrm{PS}=\mathrm{N}_{\mathrm{fr}} \times 3+\mathrm{N}_{\mathrm{so}} \times 2+\mathrm{N}_{\mathrm{ra}} \times 1+\mathrm{N}_{\mathrm{na}} \times 0
$$

Where,

$$
\begin{aligned}
& P S=\text { Participation Score } \\
& N_{\mathrm{fi}}=\text { No. of respondent participated frequently } \\
& \mathrm{N}_{\mathrm{so}}=\text { No. of respondent participated sometimes } \\
& \mathrm{N}_{\mathrm{ra}}=\text { No. of respondent participated rarely } \\
& \mathrm{N}_{\mathrm{na}}=\text { No. of respondent not at all participated }
\end{aligned}
$$

Participation index score (PIS) is the score obtained by an activity against all respondents. To compare the level of participation in four major aspects as well as twenty issues a participation extent (PE) for each of the four major aspects and twenty issues was calculated by using the following formula:

$$
\mathrm{PE}=\frac{\mathrm{OPS}}{P P S} \times 100
$$

Where,

$$
\begin{aligned}
& \text { PE = Participation Extent } \\
& \text { OPS = Observed Participation Score } \\
& \text { PPS = Possible Participation Score }
\end{aligned}
$$


As there were 92 women, so Participation Index Score (PIS) could range 0-276. Where ' 0 ' indicated no participation and '276' indicated the highest participation. Participation scores of a woman could range from 0 to 60 , where 0 indicating no participation and 60 indicating the highest participation. On the basis of Participation Extent (PE), the four aspects as well as twenty issues were ranked to compare the level of participation by the women in selected aspect and issues. The statistical measures such as number, percentage, mean, standard deviation, minimum, maximum, rank order were used for describing the variables. The analysis was performed using statistical software Statistical Package for the Social Sciences (SPSS). Spearman rho Coefficient of Correlation $(\rho)$ was employed in order to explore the relationships between the concerned variables.

\section{Results and Discussion}

The highest proportion (43.48\%) of the women belonged to young aged category followed by $36.96 \%$ middle and $19.56 \%$ old aged. The result also indicates that the participation of young aged women were dominant in participation in rooftop gardening. Majority $(52.2 \%)$ of the women were under secondary education category, while $21.7 \%$ were under above higher secondary, $14.1 \%$ were under higher secondary, and $6.5 \%$ were under primary level of education. Rest $5.4 \%$ women were illiterate. Majority $(51.1 \%)$ of the women belonged to the small sized family, while $42.4 \%$ and $6.5 \%$ of the respondents belonged to medium size and large size family, respectively. The findings also indicate that the participation was found dominant in the case of the respondents having small and medium sized family. This might be due to that they have spent less time behind the family members as their family size is less. Most $(91.3 \%)$ of the women had high income, while $7.6 \%$ had medium income and only $1.1 \%$ had low income. Three-fourth $(75 \%)$ of the women had medium cosmopoliteness, while $23.9 \%$ had high and $1.1 \%$ had low cosmopoliteness. Women having medium to high cosmopoliteness were interested in rooftop gardening. Most (81.5\%) of the women had low extension contact, while $13 \%, 4.3 \%$ and $1.1 \%$ had medium extension contact, no extension contact, and high extension contact, respectively. About $94 \%$ of the women had no training. $4.3 \%$ women had low training, and a similar percentage $(1.1 \%)$ of women had medium and high training. Most $(92.4 \%)$ of the women had no organizational participation, whereas $6.5 \%$ and $1.1 \%$ women had low and high organizational participation, respectively. Majority $(57.6 \%)$ of the women had highly favorable and $42.4 \%$ had favorable attitude towards rooftop gardening. Half $(50.0 \%)$ of the women had moderate knowledge towards rooftop gardening compared to $47.8 \%$ having high knowledge, and $2.2 \%$ having less knowledge (Table 1 ). 


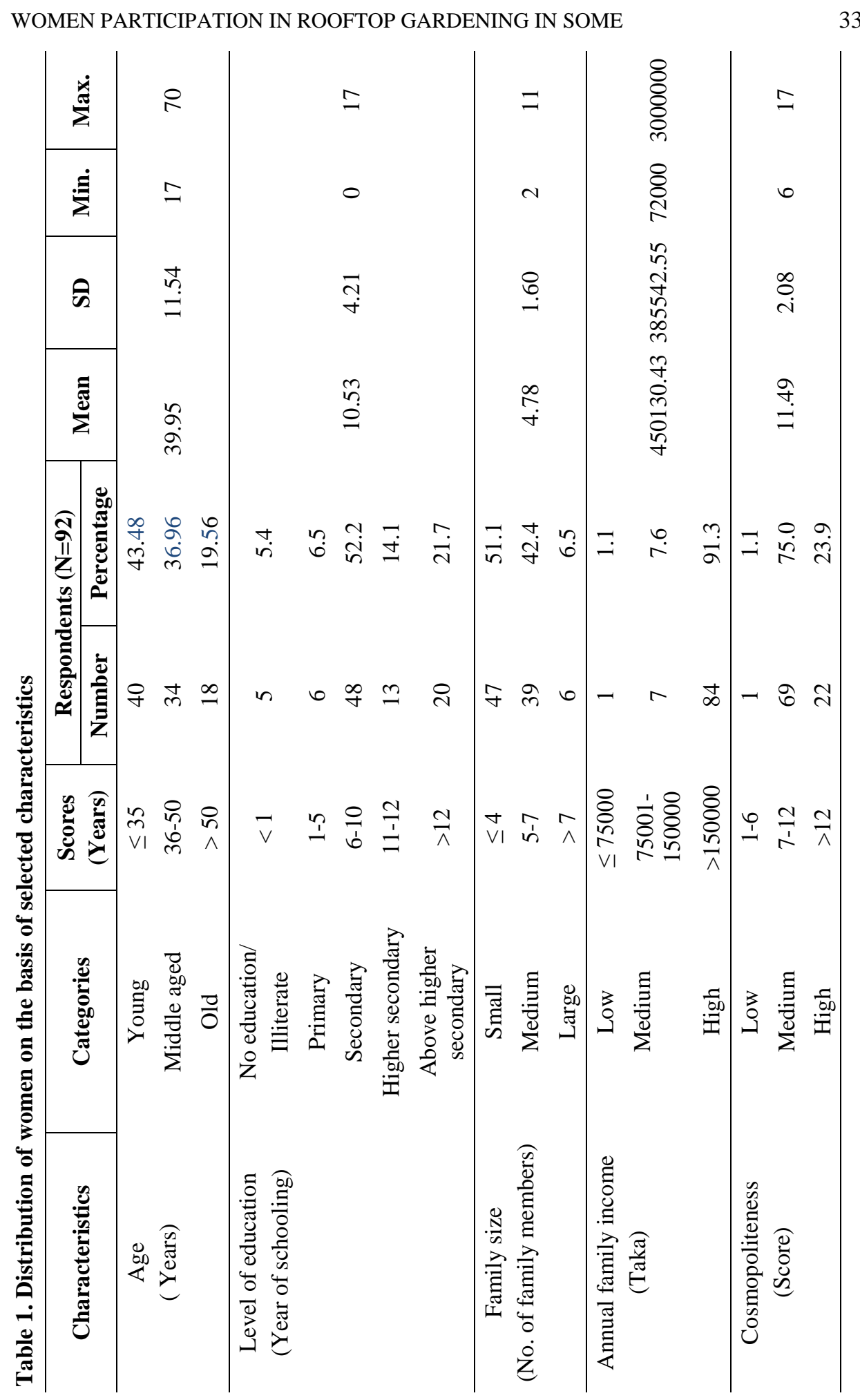




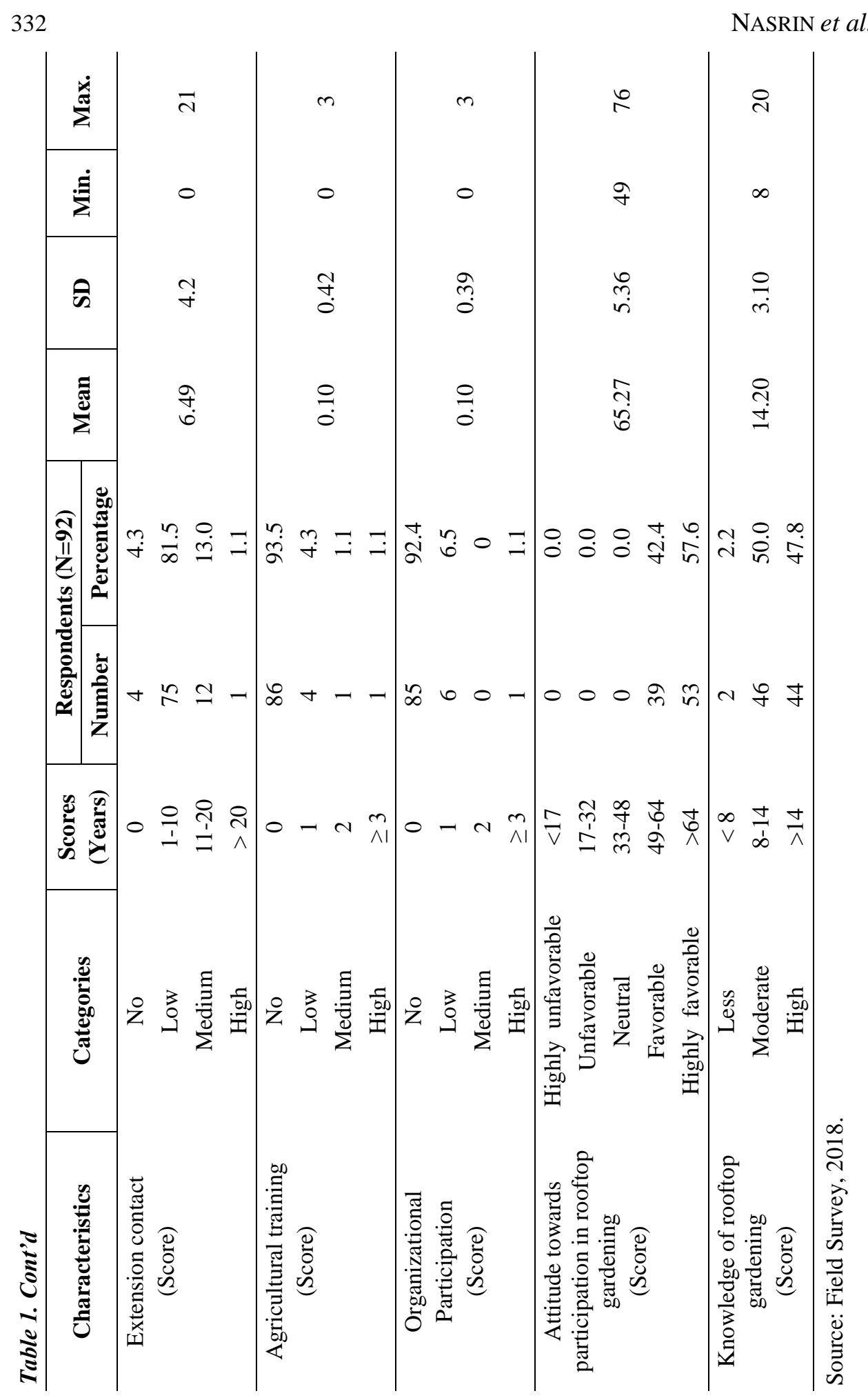




\section{Participation of Women in Rooftop Gardening}

The participation scores of the respondents in rooftop gardening ranged from 18 to 44 against possible range of $0-60$. The mean was 31.05 with a standard deviation of 4.50. The distribution of the respondents according to their extent of participation in rooftop gardening is shown in Table 2. Most (94.57\%) of the women had medium participation towards rooftop gardening compared to $3.26 \%$ having high participation and $2.17 \%$ having low participation. That means most of the women had medium to high participation in rooftop gardening.

Table 2. Distribution of women according to their level of participation in rooftop gardening

\begin{tabular}{|c|c|c|c|c|c|c|c|}
\hline \multirow{2}{*}{$\begin{array}{c}\text { Level of } \\
\text { participation }\end{array}$} & \multirow[t]{2}{*}{ Scores } & \multicolumn{2}{|c|}{ Respondents ( $N=92)$} & \multirow[t]{2}{*}{ Mean } & \multirow[t]{2}{*}{ SD } & \multirow[t]{2}{*}{ Min. } & \multirow[t]{2}{*}{ Max. } \\
\hline & & Number & Percentage & & & & \\
\hline Low & $1-20$ & 2 & 2.17 & \multirow{4}{*}{31.05} & \multirow{4}{*}{4.50} & \multirow{4}{*}{18} & \multirow{4}{*}{44} \\
\hline Medium & $21-40$ & 87 & 94.57 & & & & \\
\hline High & $41-60$ & 3 & 3.26 & & & & \\
\hline Total & & 92 & 100 & & & & \\
\hline
\end{tabular}

Source: Field Survey, 2018.

\section{Extent of Participation of Women in Rooftop Gardening}

In order to measure the extent of participation of the women the total participation was divided into four aspects including 20 selected issues and their participation extent (PE) was calculated. The four aspects as well as the 20 issues were ranked on the basis of PE (Table 3).

Table 3. Rank order of the selected four aspects including twenty issues of women in rooftop gardening based on participation extent (PE)

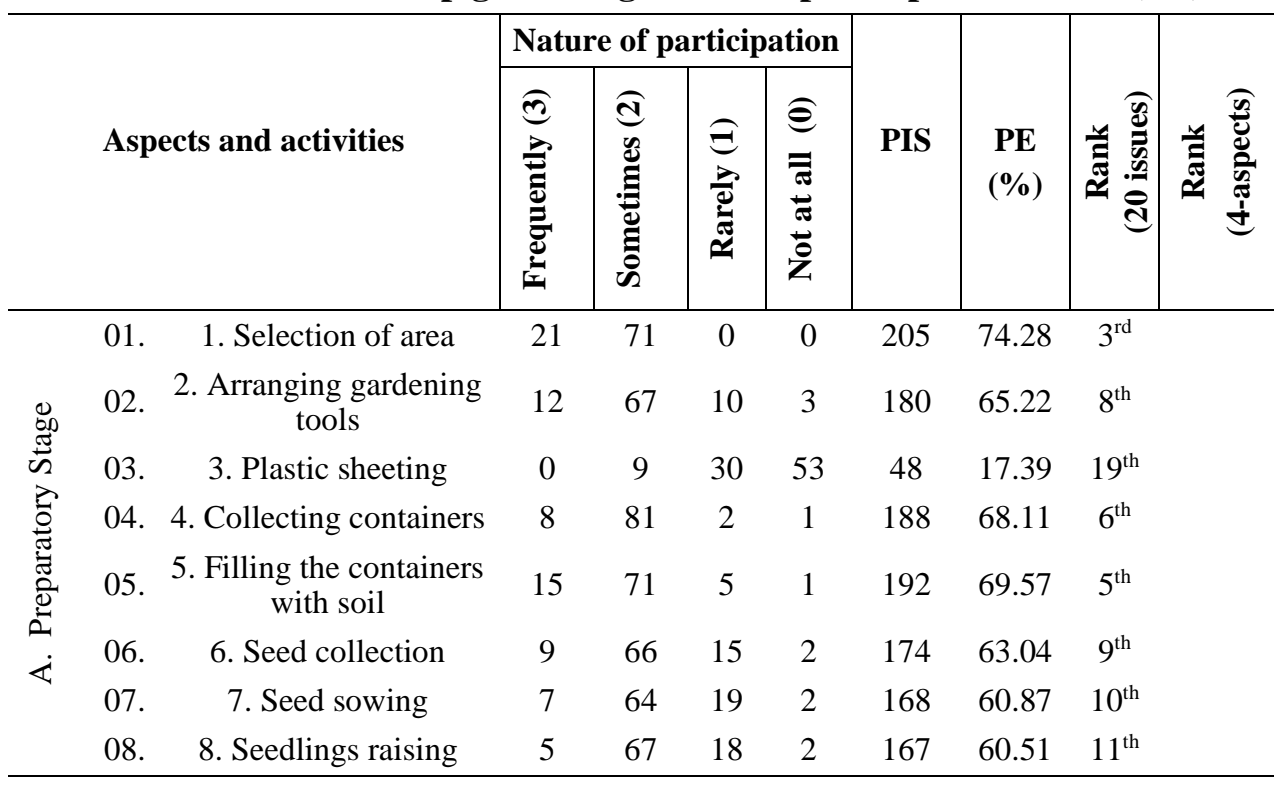


Table 3. Cont'd

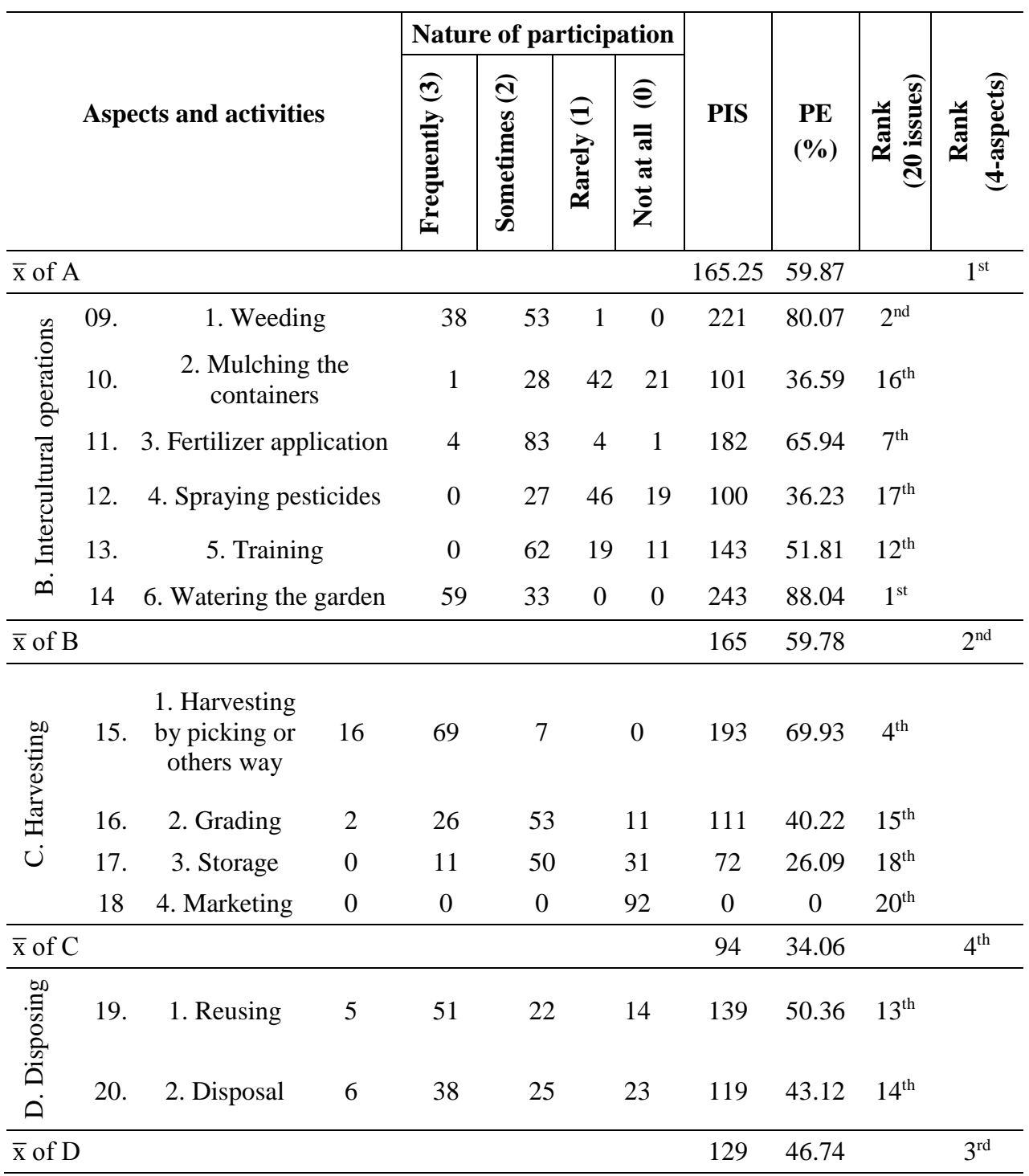

Source: Field Survey, 2018.

Table 3 indicates that the women participation was highest in preparatory stage $(\overline{\mathrm{x}}=165.25)$ while it was least in harvesting stage $(\overline{\mathrm{x}}=94.00)$. The other aspects of rooftop gardening as participated by the women were in intercultural operations $(\overline{\mathrm{x}}=165.00)$ followed by disposing $(\overline{\mathrm{x}}=129.00)$ stage. Considering twenty issues the highest participation of the women was observed in watering the garden followed by weeding, selection of area and so on and the women had no participation in marketing. 
Sheel et al. (2019) found that average roof area was $1,305 \mathrm{ft}^{2}$, average suitable roof area for gardening was $949.17 \mathrm{ft}^{2}$, and average actual roof area under garden was $582.67 \mathrm{ft}^{2}$ in Khulna city. Various plants of diversified importance were grown in those rooftop gardens. The name of most common flowers, vegetables, fruits, medicinal plants and other types of plants grown in rooftop garden in the study area have been presented in Table 4 . The researcher took notes on the available types of plants in the rooftop gardens in the study area.

As per the number of available species, fruits were the most diversified followed by flowers, vegetables and medicinal plants. Some other plants such as cactus, bonsai, dracaena, palm, henna and croton were also available in the rooftop gardens.

Table 4. Types of plants grown in rooftop garden

\begin{tabular}{|c|c|}
\hline Plant types & Names of species \\
\hline $\begin{array}{l}\text { Flowers } \\
\text { (12 species) }\end{array}$ & $\begin{array}{l}\text { Rose, marigold, bougainvillea, Arabian jasmine, chrysanthemum, } \\
\text { cape jasmine, Chinese rose, periwinkle, zinnia, night jasmine, } \\
\text { dahlia, gardenia }\end{array}$ \\
\hline $\begin{array}{l}\text { Vegetables } \\
(8 \text { species })\end{array}$ & $\begin{array}{l}\text { Chili, brinjal, Indian spinach, tomato, bottle gourd, bitter gourd, } \\
\text { lady's finger, coriander }\end{array}$ \\
\hline $\begin{array}{l}\text { Fruits } \\
\text { (13 species) }\end{array}$ & $\begin{array}{l}\text { Lemon, mango, guava, sapota, jujube, pomegranate, wax jumbo, } \\
\text { lime, orange, malta, hog palm, litchi, papaya }\end{array}$ \\
\hline $\begin{array}{l}\text { Medicinal plants } \\
(5 \text { species })\end{array}$ & Aloe, basil, air plant, diabetic plant, centella \\
\hline $\begin{array}{l}\text { Other } \\
\text { (6 species) }\end{array}$ & Cactus, bonsai, dracaena, palm, henna, croton \\
\hline
\end{tabular}

Source: Field Survey, 2018.

\section{Relationship between the Selected Characteristics of the Women and their Participation in Rooftop Gardening}

Table 5 indicates that among ten characteristics of the women, the level of education, agricultural training, attitude towards rooftop gardening, and knowledge about rooftop gardening showed significant and positive relationship with their participation, meaning that these characteristics might have contributed to increased level of participation in rooftop gardening by women. The rest of the characteristics viz. age, family size, annual family income, cosmopoliteness, extension contact, organizational participation did not show any significant relationship with their participation in rooftop gardening. 
Table 5. Relationship between the selected characteristics of women and their participation in rooftop gardening

\begin{tabular}{l|l|c|c}
\hline Focused issue & \multicolumn{1}{|c|}{ Selected characteristics } & $\begin{array}{c}\text { Correlation } \\
\text { coefficient }(\boldsymbol{\rho})\end{array}$ & P value \\
\hline & 1. Age & $0.140^{\mathrm{NS}}$ & 0.183 \\
& 2. Level of education & $0.222^{*}$ & 0.034 \\
& 3. Family size & $-0.056^{\mathrm{NS}}$ & 0.593 \\
& 4. Annual family income & $0.117^{\mathrm{NS}}$ & 0.266 \\
Participation of & 5. Cosmopoliteness & $-0.126^{\mathrm{NS}}$ & 0.230 \\
women in rooftop & 6. Extension contact & $0.147^{\mathrm{NS}}$ & 0.163 \\
gardening & $\begin{array}{l}\text { 7. Agricultural training } \\
\text { 8. Organizational participation }\end{array}$ & $0.270^{* *}$ & 0.009 \\
& $\begin{array}{l}\text { 9. Attitude towards rooftop } \\
\text { gardening }\end{array}$ & $0.319^{\mathrm{NS}}$ & 0.108 \\
& $\begin{array}{l}\text { 10. Knowledge about rooftop } \\
\text { gardening }\end{array}$ & $0.368^{* *}$ & 0.003 \\
\hline
\end{tabular}

$\mathrm{NS}=$ Non-significant, $* *$ Correlation is significant at the 0.01 level (2-tailed), ${ }^{*}$ Correlation is significant at the 0.05 level (2-tailed).

Source: Field Survey, 2018.

\section{Conclusion}

Almost all of the women had medium to high participation in rooftop gardening. The women had higher participation in preparatory stage and it was least in harvesting stage. Considering 20-issues under 4-aspects of rooftop gardening, the highest participation by the women was in watering the garden and no participation was in marketing.The findings revealed that level of education, agricultural training, attitude towards rooftop gardening and knowledge about rooftop gardening showed significant and positive relation with participation in rooftop gardening.Therefore, it may be concluded that the more the education, agricultural training, attitude towards rooftop gardening and knowledge about rooftop gardening the more the participation in rooftop gardening. Rooftop gardening should be considered as an important source of additional agricultural production by inspiring the barrier free participation of the city dwelling women by designing women friendly extension approach.

\section{References}

Abram, P. 2006. Verde Pensile in Italia ed Europa. Milan: llverdie editorial.

Akbari, H. M. Pomerantz and H. Taha. 2001. Cool surfaces and shade trees to reduce energy use and improve air quality in urban areas. Sol. Energy, 70: 295-310. 
Baumann, N. 2006. Ground-nesting birds on green roofs in Switzerland: Preliminary observations. Urban Habitats, 4: 37-50.

Cantor, S.L. 2008. Green Roofs in Sustainable Landscape Design. W.W. Norton \& Company, New York, USA.

Chrisman, S. 2005. Green Roofs: Ecological Design and Construction. Earth Pledge. Schiffer Publishing Ltd., Pennsylvania, USA.

Costanzo, V., G. Evola and L. Marletta. 2016. Energy savings in buildings or UHI mitigation? Comparison between green roofs and cool roofs. Energy and Buildings, 114: $247-255$.

Grant, G. 2006. Extensive green roofs in London. Urban Habitats, 4: 51-65.

Nowak, M., 2004. Urban Agriculture on the Rooftop. City Farmer, Canada's Office of Urban Agriculture.

Quasem, M.A. 2011. Conversion of Agricultural Land to Non-agricultural uses in Bangladesh: Extent and Determinants. Bangladesh Dev. Stud., 34: 59-85.

Rowe, D.B., M.A. Monterusso and C.L. Rugh. 2006. Assessment of heat-expanded slate and fertility requirements in green roof substrates. Hort Technology, 16: 471-477.

Sheel, M., M.B. Ahmed, S.A.K.U. Khan and M.M. Islam. 2019. Present scenario and problem confrontation of rooftop gardening and its efficacy in ambient environment reclamation in Khulna City of Bangladesh, Fundamental and Applied Agriculture 4(1): 617-626. doi: 10.5455/faa.2656.

USEPA [US Environmental Protection Agency]. 2000.Vegetated Roof Cover: Philadelphia, Pennsylvania. Washington (DC): USEPA. Report no. EPA 841-B-00005D.

Weiler, S. and K. Scholz-Barth. 2009. Green Roof Systems: A Guide to the Planning, Design, and Construction of Landscapes over Structure, Wiley \& Sons, Inc., New Jersey, USA.

Wong, N.H., Y. Chen, C.L. Ong and A. Sia. 2003.Investigation of Thermal Benefits of Rooftop Garden in the Tropical Environment. Building and Environment, 38: 261270. 
